\title{
Evaluation of Biochemical Parameters of Rats Fed with Corn Flour Supplemented with Cricket (Acheta gossypii) Proteins
}

Elijah Edache Ehoche*
Akanya Helmina
Adefolalu Funmilola Sherifat
Department of Biochemistry, Federal
University of Technology, Minna,
Minna, Niger State, Nigeria
*email: elaijahee@gmail.com
Keywords:
Corn
Cricket
Diets
Supplementation

\begin{abstract}
African staple diets are mainly of protein-deficient corn. Dried yellow corn was fermented, dried, ground and supplemented with $5 \%$ and $10 \%$ of cricket (Acheta gossypii) flour. A standard diet of 5\% and 10\% soybean proteins-based corn flour was also prepared. The diets were fed to albino rats for four weeks. Standard methods for the serum levels of alkaline phosphatase (ALP), aspartate transaminase (AST), alanine transaminase (ALT), total proteins (TP), and albumin were determined in albino rats using $5 \%$ and $10 \%$ soybean supplemented corn diets as standard diets. The serum levels of ALP, AST, ALP, TP, and albumin in the rats fed with cricket supplemented diets were in the range of the normal healthy animals but were significantly different from the cornflour and soybean supplemented diets such that the ALP and AST values of the rats fed on the cornflour significantly decreased over the soybean supplemented and cricket supplemented experimental diets. The ALT activity, TP, and albumin levels of the rats fed the cornflour, and the soybean supplemented diets were significantly lower than those fed on the cricket protein supplemented diet $(\mathrm{p}<0.05)$. Supplementing corn with crickets has shown improvement in the nutritional quality of corn, therefore, may be used to solve the malnutrition.
\end{abstract}

Received: September $11^{\text {th }} 2019$

Accepted: October 22nd 2019

Published: November 14th 2019

(c) 2019 Elijah Edache Ehoche, Akanya Helmina, Adefolalu Funmilola Sherifat. Published by Institute for Research and Community Services Universitas Muhammadiyah Palangkaraya. This is an Open Access article under the

\section{INTRODUCTION}

Hunger is on the rise in Nigeria and the underdeveloped countries. There is a massive problem of protein malnutrition and food shortages (Semba, 2016). The number of undernourished people has increased from around 804 million people in 2016 to around 821 million in 2017 and is worsening in developing nations of the world (Food and Agriculture Organization of the United Nations, 2019). The increase in the population of people had led to a higher demand for food. Furthermore, there is a dwindling economic crisis across the globe, especially in Africa and other developing countries (Kearney, 2010). Foods, if available, are not affordable. This has placed many people in a state where accessibility to regular food becomes difficult and unaffordable. This creates a need for a cheaper and affordable food source (Tacoli, 2017; Kimani-Murage et al., 2014).

Corn (Zea mays) is farmed as an everyday staple across the Savannah regions of Africa. Corn is cheap but deficient in proteins (Nuss \& Tanumihardjo, 2011). This could be improved by supplementing cornflour with cricket (Acheta gossypii) proteins. Crickets are available, but underutilized (Stull et al., 2018). Since corn is cheap and crickets are available, protein malnutrition, as well as food shortages, could be reduced by supplementing cornflour with cricket (Gunaratna et al., 2019; Henchion et al., 2017). 
In certain parts of Africa including Nigeria, crickets, like other insect is ubiquitous in its various species both at home and in the wild (Oonincx et al., 2015; Havlik et al., 2014). Various species of crickets are reportedly consumed as snacks among the lower class in Africa. However, Brachytrupes membranaceus, Gryllus bimaculatus De Geer, Acheta spp., and Henicus whellani are the most common species eaten (Musundire et al., 2014). These all belong to the order orthoptera with high proteins (43.9$77.1 \mathrm{~g} / \mathrm{kg}$ ) and energy values (3319.3-5239.7 kJ/kg) as reported by Kelemu et al. (2015). Crickets can also be farmed with a turnover of just six weeks it could serve as a better protein alternative to others sources like beef that takes years and other expensive resources to be rared before conversion to meat (van Huis \& Oonincx, 2017). More so, crickets have the more efficient conversion of phytomass to zoomass and the land required to farm crickets highly negligible per protein mass-produced when compared to the conventional sources as well producing less harmful gases that are capable of altering the climate (Rumpold \& Schlüter, 2013).

In evaluating the nutritional quality of any food, the protein quality is the most important. Estimation of the protein quality involves the quality of the proteins as well as the digestibility (Wolfe et al., 2016). Also, for new diets, safety and sustainable and non-toxic foods are of significant concern. Many corn-based diets are lacking in the nutrient, as mentioned earlier composition partially due to its low protein content (Sebastiani et al., 2019). There is a need, for this reason, for the development of affordable diet with sufficient proteins that could support growth and development in children as well as in adults from available and acceptable raw resources with the use of easy processing methods which can be accessible and affordable to the poor and the average Nigerian (Chadare et al., 2019).
Based on this background, this study aims to determine the biochemical parameters of test animals given a mixture of cornflour with cricket. As a test animal, male albino rats are used. The biochemical parameters observed were serum concentrations of alkaline phosphatase (ALP), aspartate transaminase (AST), alanine transaminase (ALT), total proteins (TP), and albumin.

\section{MATERIALS AND METHODS}

\section{Materials}

Assay Kits for ALP, AST, ALT, TP, and albumin determination, were products of Randox Laboratory Limited, County Atrim, United Kingdom. All the chemicals used were of general-purpose grade manufactured by the British Drug House (BDH) Limited, Poole, England and Sigma Aldrich Chemical Company Incorporation, Wisconsin, USA.

\section{Tools}

Tools used include the Beckman refrigerated centrifuge (TJ-6 model, USA), rotary evaporator (RE500 Yamato Scientific America Incorporation, USA), UV-Vis spectrophotometer (UV-1800 models, USA) analytical balance (Ohaus Adventurer model A223CN), water bath (Light Water, Surrey GU185TA, UK) medium-scale grinding engine (Henry West G160, 5.5 HP) moisture extraction oven (Gallenkamp, size 2, Brainweigh B, UK) and hot plate (Biotec, India).

\section{Samples collection, identification, and treatment}

The yellow corn samples were bought from Maikunkele Market, Bosso Local Government, Minna, Niger State, Nigeria and was identified in the Department of Plant Biology, Federal University of Technology, Minna. The corn kernels were cleaned steeped in a plastic container to ferment for 68 hours to allow for fermentation without sprouting. The fermented product was rinsed with clean 
water and sun-dried after which they were wholly grinded severally to powder using an electric grinder. This was kept in a plastic container for further analyses. The roasted cricket flour sample was commercially obtained from Ankpa roadside market, Ankpa Local Government, Kogi State, Nigeria. Also, the cricket flour was identified at the Department of Plant Biology, Federal University of Technology, Minna. The roasted cricket was grinded into flour and stored in plastic containers for analyses. The soybean (Glycine max) sample was obtained from Bosso market, Bosso Local Government, Minna, Niger State, Nigeria. The samples were also identified in the Department of Animal Biology, Federal University of Technology, Minna. The dry soybean seed samples were washed, sun-dried and wholly grinded severally to powder using an electric grinder.

\section{Formulation of cricket supplemented corn flour diets}

The diets were formulated into $5 \%$ and $10 \%$ cricket supplements. The formulation was done based on the percentage of the cricket and corn flours respectively, to yield an increment of $5 \%$ and $10 \%$ cricket content in the experimental diets. The diets were kept in plastic containers for further analyses. The same procedure was repeated for soybean-based diets (Hanboonsong \& Durst, 2014).

\section{Determination of biochemical parameters}

The methods for determining the biochemical parameters used were as described by Chauynarong et al. (2009) and Seralini et al. (2007). Twenty healthy male albino rats of an average initial weight of $68.42 \mathrm{~g}$ were fed with standard rat feed to acclimatize for 48 hours and grouped randomly into five groups. The experimental design was as shown in Table I.

\begin{tabular}{ccc} 
Table I. & Experimental design & \\
\hline $\begin{array}{c}\text { Animal } \\
\text { groups }\end{array}$ & Diet used as feed & Code \\
\hline A & Free-corn flour supplement & 0 \\
B & $5 \%$ cricket supplemented diet & C 5 \\
C & $10 \%$ cricket supplemented diet & C10 \\
D & $5 \%$ soybeans supplemented diet & S5 \\
E & $10 \%$ soybeans supplemented diet & S10 \\
\hline
\end{tabular}

Each group was housed and fed by the aid of a metal trough fitted to a corner of the housing cage, and at the same time, water was provided using an overhead nipple drinker for each cage. Each of the cages was cleaned every day. Feed and water were supplied adlibitum and feed intake were calculated in g. The weekly weight change was also recorded total feed intake, and total weight change of each rat was recorded from the corresponding weekly live weight change up to the end of the feeding period. After the 28 days feeding period, the animals were anaesthetized with chloroform. Each anaesthetized animal was sacrificed, and blood was collected. As much as $1 \mathrm{~g}$ blood collected carefully from the sacrificed animals with the aid of a pair of gloves and dissecting instruments, into $15 \mathrm{ml}$ sucrose $0.25 \mathrm{~N}$ and then homogenized. The supernatant was carefully decanted into specimen bottles and kept below $4^{\circ} \mathrm{C}$ for assay.

\section{Alkaline phosphatase assay}

In a cuvette, $10 \mu \mathrm{l}$ of the sample was mixed with $500 \mu \mathrm{l}$ of Randox reagent (a solution containing $p$-NPP in full). The initial absorbance was read at $405 \mathrm{~nm}$, and subsequently over three minutes. The mean absorbance per minute was used in the calculation:

$$
\text { ALP activity }(I U / l)=2742 \times \Delta A 405 \mathrm{~nm} / \mathrm{min}
$$

$2742=$ Extinction coefficient of Absorbance;

$\Delta \mathrm{A} 405 \mathrm{~nm} / \mathrm{min}=$ change in absorbance per minute for the homogenate sample

Aspartate phosphatase assay

The sample (50 $\mu$ l) was mixed with $500 \mu \mathrm{l}$ of the AST reagent in a test tube, and the initial absorbance at $340 \mathrm{~nm}$ was read after a minute. The timer was started 
simultaneously, and further readings of the absorbance were taken after 1, 2, and 3 minutes and calculations were made as below:

$$
\text { AST activity }(\mathrm{nm} / \mathrm{min})=1746 \times \Delta A 340 \mathrm{~nm} / \mathrm{min}
$$

$\Delta \mathrm{A} 340 \mathrm{~nm} / \mathrm{min}=$ change in absorbance per minute for the homogenate sample,

$1746=$ Extinction coefficient of $1 \mathrm{M}$ Absorbance of $\mathrm{NADH} / \mathrm{NAD}^{+}$

\section{Alanine transaminase assay}

The sample $(50 \mu \mathrm{l})$ and $500 \mu \mathrm{l}$ of the ALT reagent were mixed in a test tube, and the initial absorbance at $340 \mathrm{~nm}$ was read after a minute. The timer was started simultaneously, and further readings of the absorbance were taken after 1,2 , and 3 minutes and calculations were made:

\section{ALT activity $(\mathrm{nm} / \mathrm{min})=1746 \times \Delta A 340 \mathrm{~nm} / \mathrm{min}$}

$\Delta \mathrm{A} 340 \mathrm{~nm} / \mathrm{min}=$ change in absorbance per minute for the homogenate sample,

1746 $=$ Extinction coefficient of Absorbance.

\section{Total protein assay}

In a cuvette, $10 \mu \mathrm{l}$ of blank (distilled water) was mixed with $1 \mathrm{ml}$ of the Biuret reagent. It was left to incubate for ten minutes. Then the absorbance was read at $546 \mathrm{~nm}$. The procedure was followed for the standard and the sample and repeated three times. The mean absorbance was used in the calculation:

$$
C \text { sample }=\frac{A \text { Sample } x \text { C Standard }}{A \text { Standard }}
$$

A: absorbance $(\AA)$

C: concentration

\section{Albumin assay}

In a cuvette, $10 \mu 1$ of blank (distilled water) was pipetted and mixed with $1 \mathrm{ml}$ of Randox reagent (R1). It was left to incubate for three minutes. Then, the absorbance was read at $628 \mathrm{~nm}$. The procedure was followed for the standard and the sample and repeated three times. The mean absorbance was used in the calculation:

A: absorbance $(\AA)$

$$
\text { C sample }=\frac{\text { A Sample } x \text { C Standard }}{A \text { Standard }}
$$

C: concentration

\section{Statistical analysis}

Data obtained were subjected to statistical analysis for the determination of mean and standard deviation values using Microsoft excel. Separate determinations for the significant differences $(p<0.05)$ between the mean values were analyzed using the Duncan's Multiple Range Test with Statistical Package for Social Statistics (SPSS) 15.0 (Ajibola et al., 2016).

\section{RESULTS AND DISCUSSION}

Biochemical parameter test results from male albino rat blood samples given variations of the dietary supplement cricket and soybean are presented in Table II. The ALP activity values of the rats fed on the cornflour diet were significantly lower than the soybean and cricket supplemented diets. The ALP activity values between the rats fed with the cricket supplemented diets were not significantly $(p>0.05)$ different from each other. The ALP activity values in the rats fed the soybean supplemented diets were significantly different from each other and all other diets ( $p<0.05)$. The AST activity values of the rats fed the cornflour, and the rats fed the soy supplemented diets were significantly higher than in the rats fed the $5 \%$ and $10 \%$ cricket supplemented diets ( $\mathrm{p}<0.05)$. The ALT activity of the rats fed the cornflour, and the soy supplemented diets were significantly $(p<0.05)$ lower than those fed with the cricket supplemented diets $(p$ $<0.05)$. As with the ALT, a similar pattern was obtained with albumin, and total protein values in the rats fed the various diets.

Table II. Effects of experimental diets on biochemical parameters in male albino rats

\begin{tabular}{lccccc}
\hline \multirow{3}{*}{ Groups } & \multicolumn{5}{c}{ Biochemical parameters } \\
\cline { 2 - 6 } & $\begin{array}{c}\text { ALP } \\
(\mathbf{U} / \mathrm{L})\end{array}$ & $\begin{array}{c}\text { AST } \\
(\mathbf{U} / \mathrm{L})\end{array}$ & $\begin{array}{c}\text { ALT } \\
(\mathbf{U} / \mathrm{L})\end{array}$ & $\begin{array}{c}\text { TP } \\
(\mathrm{g} / \mathrm{dl})\end{array}$ & $\begin{array}{c}\text { Albumin } \\
(\mathrm{g} / \mathrm{dl})\end{array}$ \\
\hline Corn flour & $55.0 \pm$ & $37.9 \pm$ & $10.9 \pm$ & $3.80 \pm$ & $3.75 \pm$ \\
& $10.0^{\mathrm{a}}$ & $10.0^{\mathrm{b}}$ & $2.65^{\mathrm{b}}$ & $2.50^{\mathrm{b}}$ & $0.16^{\mathrm{b}}$ \\
$5 \%$ cricket & $82.5 \pm$ & $13.8 \pm$ & $14.7 \pm$ & $4.09 \pm$ & $3.72 \pm$ \\
& $38.9^{\mathrm{c}}$ & $0.00^{\mathrm{a}}$ & $3.62^{\mathrm{c}}$ & $0.05^{\mathrm{b}}$ & $0.16^{\mathrm{b}}$ \\
$10 \%$ & $82.5 \pm$ & $18.9 \pm$ & $15.2 \pm$ & $5.04 \pm$ & $4.09 \pm$ \\
cricket & $20.0^{\mathrm{bc}}$ & $12.1^{\mathrm{a}}$ & $0.27^{\mathrm{c}}$ & $1.33^{\mathrm{c}}$ & $0.16^{\mathrm{b}}$ \\
\hline
\end{tabular}




\begin{tabular}{lccccc}
\hline $5 \%$ & $96.3 \pm$ & $61.2 \pm$ & $9.40 \pm$ & $2.60 \pm$ & $2.77 \pm$ \\
soybean & $13.8^{\mathrm{c}}$ & $10.8^{\mathrm{c}}$ & $1.30^{\mathrm{a}}$ & $1.37^{\mathrm{a}}$ & $0.83^{\mathrm{a}}$ \\
$10 \%$ & $68.8 \pm$ & $58.8 \pm$ & $11.3 \pm$ & $2.79 \pm$ & $3.00 \pm$ \\
soybean $^{*} 19.5^{\mathrm{b}}$ & $2.34^{\mathrm{c}}$ & $3.00^{\mathrm{b}}$ & $2.90^{\mathrm{a}}$ & $0.60^{\mathrm{a}}$ \\
References $^{*}$ & $50.0-$ & $10-$ & $10-$ & $4.0-$ & $3.8-4.8$ \\
& 128 & 45 & 35 & 6.5 &
\end{tabular}

a, b,c values with different superscript are significantly different from each other $(\mathrm{p}<0.05)$.

* (Kong et al., 2016; van Huis et al., 2013).

The results obtained showed a not too significant difference from the supplementation of both cricket and soybean at a concentration of $5 \%$ and $10 \%$, except for ALP in soybean supplements. However, compared to references from previous studies by Kong et al. (2016) and van Huis et al. (2013), the average value indicated is still in the range of the results of previous studies. While in general, the use of cricket supplements showed an increase in the parameters of ALT, TP, and albumin compared to soybean. Conversely, on AST parameters, the results shown by the use of cricket are much lower than soybean.

Serum enzymes are biomarkers for the toxicity of some substances in animals. Some insects secrete toxic chemicals for self-defence. They might also harbour microorganism, which could be a source of toxicity when consumed as food (Schrogel \& Watjen, 2019; Kim et al., 2019). Although no known toxic chemical substance had been attributed to cricket (van Huis, 2013), there is a need to probe the chance of toxicity that may arise. The enzymatic activity of serum enzymes of the rats fed with the cricket supplemented diets agrees with the range of values reported by Kong et al. (2016) and van Huis et al. (2013), which are in the normal safe range. This suggests that subject to histochemical analysis of the underlying organs, and the diets are healthy.

The increased activity of AST in the rats fed with the soybean protein supplemented diet (5 and $10 \%$ ) could point to the fact that increase in supplementation with soybean protein could be hepatotoxic in rats. Although no clinical sign was noticed, continuous intake of the supplemented diets could lead to toxicity (Lee et al., 2015).
This makes the cricket supplemented diets more superior to the soybean protein supplemented diets.

On the other hand, the low levels of the total serum proteins and albumin in the animals placed on the cornflour is a result of low protein level in cornflour (Table II). The low levels of serum proteins and albumin in the animals placed on the $5 \%$ and $10 \%$ soybean diet could be attributed to the possible presence of antinutritional factor in soybean (Gu et al., 2010).

\section{CONCLUSION}

The biochemical parameters showed that there was no significant biochemical change in the characteristics of the biomarkers of liver toxicity for all the experimental diets except for ALP in the soybean supplemented diet. Thus, cricket can be used as a supplement for the cornflour diet as a substitute for soybean.

\section{REFERENCES}

Ajibola, C.F., Fagbemi, T.N., Osundahunsi, O.F. 2016. Nutritional Quality of Weaning Foods Formulated from Maize Gruel 'Ogi' and Crayfish Using Combined Traditional Processing Technology. Advances in Research. 6(4):1-11. https://doi.org/10.9734/AIR/2016/21981

Chadare, F.J., Idohou, R., Nago, E., Affonfere, M., Agossadou, J., Fassinou, T.K., Kenou, C., Honfo, S., Azokpota, P., Linneman, A.R., Hounhouigan, D.J. 2019. Conventional and food-to-food fortification: An appraisal of past practices and lessons learned. Food Science $\mathcal{E}$ Nutrition. 7(9):2781-2795. https://dx.doi.org/10.1002/fsn3.1133

Chauynarong, N., Elangovan, A.V., Iji, P.A. 2009. The potential of cassava products in diets for poultry. World's Poultry Science Journal. 65(1):23-36. https://doi.org/10.1017/S0043933909000026

Food and Agriculture Organization of the United Nations. 2019. The State of Food Security and Nutrition in the World 2019. Safeguarding against 
economic slowdowns and downturns. Rome: Food and Agriculture Organization of the United Nations.

Gu, C., Pan, H., Sun, Z., Qin, G. 2010. Effect of Soybean Variety on Anti-Nutritional Factors Content, and Growth Performance and Nutrients Metabolism in Rat. International Journal of Molecular Sciences. 11(3):1048-1056. https://dx.doi.org/10.3390/ijms11031048

Gunaratna, N.S., Moges, D., Groote, H.D. 2019. Biofortified Maize Can Improve Quality Protein Intakes among Young Children in Southern Ethiopia. Nutrients. 11(1):192. https://dx.doi.org/10.3390/nu11010192

Hanboonsong, Y., Durst, P.B. 2014. Edible insects in Lao PDR: building on tradition to enhance food security. Bangkok: Food and Agriculture Organization of the United Nations Regional Office for Asia and the Pacific.

Havlik, P., Valin, H., Herrero, M., Obersteiner, M., Schmid, E., Rufino, M.C., Mosnier, A., Thornton, P.K., Bottcher, H., Conant, R.T., Frank, S., Fritz, S., Fuss, S., Kraxner, F., Notenbaert, A. 2014. Climate change mitigation through livestock system transitions. Proceedings of the National Academy of Sciences of the United States of America. 111(10):3709-3714.

https://doi.org/10.1073/pnas.1308044111

Henchion, M., Hayes, M., Mullen, A.M., Fenelon, M., Tiwari, B. 2017. Future Protein Supply and Demand: Strategies and Factors Influencing a Sustainable Equilibrium. Foods. 6(7):53. https://dx.doi.org/10.3390/foods6070053

van Huis, A. 2013. Potential of insects as food and feed in assuring food security. Annual Review of Entomology. 58:563-583. https://doi.org/10.1146/annurev-ento120811-153704

van Huis, A., Itterbeeck, J.V., Klunder, H., Mertens, E., Halloran, A., Muir, G., Vantomme, P. 2013. Edible insects: future prospects for food and feed security. FAO Forestry Paper 171. Rome: Food and Agriculture Organization of the United Nations.

van Huis, A., Oonincx, D.G.A.B. 2017. The environmental sustainability of insects as food and feed. A review. Agronomy for Sustainable
Development.

$37: 43$.

https://doi.org/10.1007/s13593-017-0452-8

Kearney, J. 2010. Food consumption trends and drivers. Philosophical Transactions of the Royal Society B. 365(1554):2793-2807.

https://dx.doi.org/10.1098/rstb.2010.0149

Kelemu, S., Niassy, S., Torto, B., Fiaboe, K., Affognon, H., Tonnang, H., Maniania, N.K., Ekesi, S. 2015. African edible insects for food and feed: inventory, diversity, commonalities and contribution to food security. Journal of Insects as Food and Feed. 1(2):103-119. https://doi.org/10.3920/JIFF2014.0016

Kim, T.K., Yong, H.I., Kim, Y.B., Kim, H.W., Choi, Y.S. 2019. Edible Insects as a Protein Source: A Review of Public Perception, Processing Technology, and Research Trends. Food Science of Animal Resources. 39(4):521-540. https://dx.doi.org/10.5851/kosfa.2019.e53

Kimani-Murage, E.W., Schofield, L., Wekesah, F., Mohamed, S., Mberu, B., Ettarh, R., Egondi, T., Kyobutungi, C., Ezeh, A. 2014. Vulnerability to Food Insecurity in Urban Slums: Experiences from Nairobi, Kenya. Journal of Urban Health. 91(6):1098-1113. https://dx.doi.org/10.1007/s11524-014-98943

Kong, D.Y., Park, J.H., Lee, K.W., Park, H., Cho, J.A. 2016. Comparative Analysis of 3 Experimental Mouse Model for Blood Hematology and Chemistry. Biomedical Science Letters. 22:75-82. https://doi.org/10.15616/BSL.2016.22.3.75

Lee, D., Albenberg, L., Compher, C, Baldassano, R., Piccoli, D., Lewis, J.D., Wu, G.D. 2015. Diet in the Pathogenesis and Treatment of Inflammatory Bowel Diseases. Gastroenterology. $\quad$ 148(6):1087-1106. https://dx.doi.org/10.1053/j.gastro.2015.01.0 07

Musundire, R., Zvidzai, C.J., Chidewe, C., Samende, B.K. 2014. Nutrient and anti-nutrient composition of Henicus whellani (Orthoptera: Stenopelmatidae), an edible ground cricket, in south-eastern Zimbabwe. International Journal of Tropical Insect Science. 34(4):223-231. https://doi.org/10.1017/S1742758414000484

Nuss, E.T., Tanumihardjo, S.A. 2011. Quality Protein Maize for Africa: Closing the Protein 
Inadequacy Gap in Vulnerable Populations. Advances in Nutrition. 2(3):217-224. https://dx.doi.org/10.3945/an.110.000182

Oonincx, D.G.A.B., van Broekhoven, S., van Huis, A., van Loon, J.J.A. 2015. Feed Conversion, Survival and Development, and Composition of Four Insect Species on Diets Composed of Food ByProducts. PLoS One. 10(12):e0144601. https://dx.doi.org/10.1371/journal.pone.014 4601

Rumpold, B.A., Schlüter, O.K. 2013. Potential and challenges of insects as an innovative source for food and feed production. Innovative Food Science \& Emerging Technologies. 17:1-11. https://doi.org/10.1016/j.ifset.2012.11.005

Schrogel, P., Watjen, W. 2019. Insects for Food and FeedSafety Aspects Related to Mycotoxins and Metals. Foods. 8(8):288. https://dx.doi.org/10.3390/foods8080288

Sebastiani, G., Barbero, A.H., Borras-Novell, C., Casanova, M.A., Aldecao-Bilbao, V., AndreuFernandez, V., Tutusaus, M.P., Martinez, S.F., Roig, M.D.G., Garcia-Algar, O. 2019. The Effects of Vegetarian and Vegan Diet during Pregnancy on the Health of Mothers and Offspring. $\quad$ Nutrients. 11(3):557. https://dx.doi.org/10.3390/nu11030557

Semba, R.D. 2016. The rise and fall of protein malnutrition in global health. Annals of Nutrition and Metabolism. 69(2):79-88. https://dx.doi.org/10.1159/000449175

Seralini, G.E., Cellier, D., de Vendomois, J.S. 2007. New analysis of a rat feeding study with a genetically modified maize reveals signs of hepatorenal toxicity. Archives of Environmental Contamination and Toxicology. 52(4):596-602. https://doi.org/10.1007/s00244-006-0149-5

Stull, V.J., Finer, E., Bergmans, R.S., Febvre, H.P., Longhurst, C., Manter, D.K., Patz, J.A., Weir, T.L. 2018. Impact of Edible Cricket Consumption on Gut Microbiota in Healthy Adults, a Double-blind, Randomized Crossover Trial. Scientific Reports. 8:10762. https://dx.doi.org/10.1038/s41598-01829032-2

Tacoli, C. 2017. Food (In)Security in Rapidly Urbanising, Low-Income Contexts. International Journal of Environmental Research and Public Health.
14(12):1554.

https://dx.doi.org/10.3390/ijerph14121554

Wolfe, R.R., Rutherfurd, S.M., Kim, I.Y., Moughan , P.J. 2016. Protein quality as determined by the Digestible Indispensable Amino Acid Score: evaluation of factors underlying the calculation. Nutrition Reviews. 74(9):584-599. https://dx.doi.org/10.1093/nutrit/nuw022 